\title{
Expression of Manganese Superoxide Dismutase mRNA in the Rat Adrenal Cortex is Associated with the Occurrence of Mitochondrial Vesicular Cristae
}

\author{
Takao Okada*, Junzo Sasaki*, Takako Nomura*, Sadahiro Watanabe*, \\ Junko Matsuura*, Shigeto Kanda* and Eisuke F. Sato** \\ ${ }^{*}$ Department of Anatomy, Okayama University Medical School, Okayama 700 and ${ }^{* *}$ Department of Biochemistry, \\ Osaka City University of Medical School, Osaka 545
}

Received for publication July 14, 1995 and in revised form September 29, 1995 and re-revised form October 31, 1995

\begin{abstract}
To investigate the possible role of manganese superoxide dismutase (Mn-SOD) in steroidogenesis, we studied the expression of Mn-SOD mRNA in the adrenal gland and ovaries of normal and hypophysectomized rats by in situ hybridization. Very strong expression of Mn-SOD mRNA was detected in the zona fasciculata and the zona reticularis of the rat adrenal cortex. The expression was very low in the zona glomerulosa, and was almost negative in the adrenal medulla. The mRNA levels in the adrenal cortex and the ovaries were markedly reduced 4 days after hypophysectomy. Marked adrenocortical atrophy occurred 14 to 24 days after the operation, while levels of $\mathrm{Mn}$ SOD mRNA in the cortex remained low. Mitochondrial structure in the fasciculata cells of normal and hypophysectomized rats
\end{abstract}

were compared by electron microscopy. Mitochondria in the fasciculata cells of normal rats were characterized by dense vesicular cristae. Four days after hypophysectomy, the cristae became tubulo-vesicular in form and their density decreased significantly. Elongated mitochondria with tubular cristae appeared. Oval mitochondria with a few tubulo-vesicular cristae were present in these cells 14 days after the operation.

Our results are consistent with the hypothesis that high Mn-SOD levels might play an important role in the regulation of steroidogenesis. The possible roles of superoxide radicals and hydrogen peroxide in the formation of vesicular cristae in the mitochondria are discussed with respect to steroidogenesis.

Key words: In situ hybridization, SOD, Adrenal gland, Mitochondria, Steroid hormone

\section{Introduction}

Since reactive oxygen species have been postulated to play critical roles in the pathogenesis of various diseases [21], the action of several enzymes which degrade these reactive oxygen species has been described as scavenging. Among two isozymes of intracellular superoxide dismutases (SOD), which catalyze the dismutation of superoxide radicals to hydrogen peroxide and oxygen, one contains $\mathrm{Cu} / \mathrm{Zn}$ and is distributed within the cytoplasmic

A part of this work was presented at the 24 th annual meeting for the society of Clinical Electron Microcopy and was published in an abstract form [16].

Correspondence to: Junzo Sasaki, M. D., Department of Anatomy, Okayama University Medical School, 2-5-1 Shikatacho, Okayama 700, Japan. matrix, and the other contains $\mathrm{Mn}$ and is distributed within the mitochondrial matrix [22]. A report by Dobashi et al. [4] showed that both $\mathrm{Cu} / \mathrm{Zn}-\mathrm{SOD}$ and $\mathrm{Mn}$ SOD were localized in various tissues and suggested that the distribution of Mn-SOD in tissues such as the heart, skeletal muscle and kidney reflected their relatively high numbers of mitochondria.

Previously, Laloraya and coworkers found an inverse correlation between the levels of superoxide radical and SOD in ovaries [10] of rats during the estrous cycle, and suggested that luteininzing hormone (LH)-induced SOD might play an important role in the production of progesterone from pregnenolone. Sato et al. [19] found that the ovarian levels of Mn-SOD mRNA markedly increased after treating immature rats with pregnant mare serum gonadotropin (PMSG) and human chorionic gonadotropin (HCG). By in situ hybridization, we previously 
demonstrated increased expression of Mn-SOD mRNA in the rat ovary during the PMSG/HCG-induced ovulatory process, mainly in the theca interna cells and granulosa cells of the ovulated follicles at the early stage [18], and in the corpora lutea at the later stage [12]. Expression of Mn-SOD mRNA in the ovary during the estrous cycle occurred in the theca interna cells on Proestrus, follicular epithelial cells on Estrus, and corpora lutea on Diestrus, day 1 and day 2 . These results showed that expression of Mn-SOD mRNA in the ovary is associated with the synthesis of progesterone. To investigate the association of Mn-SOD in steroidogenesis further, we examined the expression of Mn-SOD mRNA in the adrenal cortex and ovaries of normal and hypophysectomized rats by in situ hybridization.

\section{Materials and Methods}

Wistar rats weighing between $200 \mathrm{~g}-250 \mathrm{~g}$ were used in this study. Hypophysectomy was performed at the Imamichi Institute For Animal Reproduction (Ibaraki, Japan) using the parapharyngeal approach. Successful hypophysectomy was confirmed by the interruption of the animals growth, and by physical inspection of the sella turcica. Prior to perfusion with the fixative, an aliquot of blood was drawn from the left ventricle for corticosterone measurements using anti-rat corticosterone antibodies (SRL co., Tokyo). Serum corticosterone levels in hypophysectomized rats were usually under $25.0 \mathrm{ng} / \mathrm{ml}$, while in the control rats they were about $460 \mathrm{ng} / \mathrm{ml}$. The animals were anesthetized with an intraperitoneal injection of pentobarbital 4, 7, 14 and 24 days after the operation. The excised organs were fixed with $4 \%$ paraformaldehyde in $0.1 \mathrm{M}$ phosphate buffer ( $\mathrm{pH} 7.4$ ), dehydrated with ethanol, substituted with benzene, and then embedded in paraffin. Paraffin sections, $5 \mu \mathrm{m}$ thick, were mounted on aminopropyl triethoxy silane (APS)-coated slides. For the electron microscope studies, dissected specimens were further fixed with $2.5 \%$ glutaraldehyde in $0.1 \mathrm{M}$ phosphate buffer (pH 7.4), postfixed with $1 \% \mathrm{OsO}_{4}$ in $0.1 \mathrm{M}$ phosphate buffer ( $\mathrm{pH}$ 7.4), dehydrated in acetone and then embedded in epoxy resin. Ultrathin sections were stained with uranyl acetate and lead citrate, and then observed with a JEOL $100 \mathrm{CX}$ electron microscope at $80 \mathrm{KV}$.

\section{In situ hybridization}

In situ hybridization on paraffin sections and the preparation of probes were performed as previously described [17, 18]. In brief, linearized template DNAs were made from pGEM4Z vectors containing an EcoR I-Pst I fragment (1,002 bases) of Mn-SOD. To synthesize ${ }^{35} \mathrm{~S}$-labeled antisense and sense riboprobes, linearized DNAs were transcribed with T7 or SP6 RNA polymerases in a mixture containing $1.85 \times 10^{6} \mathrm{~Bq}$ of $\left(\alpha{ }^{-35} \mathrm{~S}\right)$-UTP [15]. After removal of the unincorporated labeled nucleotides, the length of the riboprobes was adjusted to an average of approximately 150 bases by limited alkaline hydrolysis
[3]. Probes were precipitated with ethanol, and resuspended in $20 \mathrm{mM}$ dithiothreitol (DTT) solution containing $1000 \mathrm{units} / \mathrm{ml}$ of human placental ribonuclease inhibitor. Dewaxed sections were rinsed with Dulbecco's phosphate buffered saline $(\mathrm{pH} 7.0)$ containing $2 \mathrm{mg} / \mathrm{ml}$ glycine, acetylated with $0.25 \%$ acetic anhydride in $0.1 \mathrm{M}$ triethanolamine $(\mathrm{pH} 8.0)$, rinsed with $2 \times \mathrm{SSC}(1 \times \mathrm{SSC}=0.15 \mathrm{M}$ $\mathrm{NaCl}, 0.015 \mathrm{M}$ sodium citrate) and prehybridized in a solution containing $50 \%$ formamide, $2 \times \mathrm{SSC}$ and $10 \mathrm{mM}$ DTT at $50^{\circ} \mathrm{C}$ for more than $1 \mathrm{hr}$. Hybridization was performed using $20 \mu \mathrm{l}$ of a hybridization mixture containing $50 \%$ formamide, $2 \times \mathrm{SSC}, 1 \mathrm{mg} / \mathrm{ml}$ tRNA, $0.5 \mathrm{mg} / \mathrm{ml}$ sonicated salmon sperm DNA, $2 \mathrm{mg} / \mathrm{ml}$ bovine serum albumin, $100 \mathrm{mM}$ DTT, $10 \%$ dextran sulfate and the riboprobe $\left(1 \times 10^{6} \mathrm{dpm} /\right.$ slide $)$ at $50^{\circ} \mathrm{C}$ overnight in a moist chamber. The slides were then rinsed three times with $2 \times \mathrm{SSC}, 50 \%$ formamide and $10 \mathrm{mM}$ DTT at $50^{\circ} \mathrm{C}$ each for $20 \mathrm{~min}$, digested with $20 \mu \mathrm{g} / \mathrm{ml}$ RNase A in NTE $(10 \mathrm{mM}$ Tris- $\mathrm{HCl}, \mathrm{pH} 8.0,0.5 \mathrm{M} \mathrm{NaCl}, 1 \mathrm{mM}$ ethylene diamine tetraacetic acid) for $30 \mathrm{~min}$ at $37^{\circ} \mathrm{C}$. They were then rinsed with $0.1 \times \mathrm{SSC}$ and $10 \mathrm{mM}$ DTT, dehydrated with ethanol and air dried. The slides were coated with Kodak NTB2, diluted 1:1.5 with water at $42^{\circ} \mathrm{C}$. After exposed for 14 days at $4{ }^{\circ} \mathrm{C}$, they were developed with Kodak D-19 at $20^{\circ} \mathrm{C}$ for $3 \mathrm{~min}$. The sections were stained with hematoxylin and eosin and then observed by light microscopy (Olympus $\mathrm{BH}$ ) using light and dark field condensers. Some photos were taken under the same condition (exposure time etc.) to compare the amount of signal on the sections.

\section{Results}

Figs. 1-4 show the expression of Mn-SOD mRNA as revealed by in situ hybridization with the ${ }^{35} \mathrm{~S}$-labeled antisense riboprobe prepared from Mn-SOD cDNA. When sense riboprobes were used as a control, few signals were observed in the tissue sections (data not shown). The signal levels observed using sense riboprobes was equivalent to the signals observed in the adrenal medulla using antisense riboprobes (Figs. 1d, 2j). Mn-SOD mRNA was highly expressed in the zonae fasciculata (Fig. $1 \mathrm{a}, \mathrm{b}$ ) and reticularis (Fig. 1c, d), whereas it was very low in the zona glomerulosa (Fig. 1a, b) and was almost negative in the adrenal medulla (Fig. 1c, d).

Photographs (Fig. 2a-j) were taken under the same conditions for exact comparisons between different groups. The hypophysectomy procedure decreased $\mathrm{Mn}$ SOD mRNA expression in the adrenal cortex and concomitantly caused cortical atrophy. Figs. 2 shows the adrenal gland of a non-treated rat (Fig. 2a, b), 4 (Fig. 2c, d), 7 (Fig. 2e, f), 14 (Fig. 2g, h) and 24 (Fig. 2i, j) days after the operation. The expression of Mn-SOD mRNA in the thin cortex was low (Fig. $2 \mathrm{j}$, arrowhead), though it was higher than that in hepatocytes of normal rats (Fig. 3a, b). A decrease in Mn-SOD mRNA expression was also seen in the ovaries 4 days after hypophysectomy. 

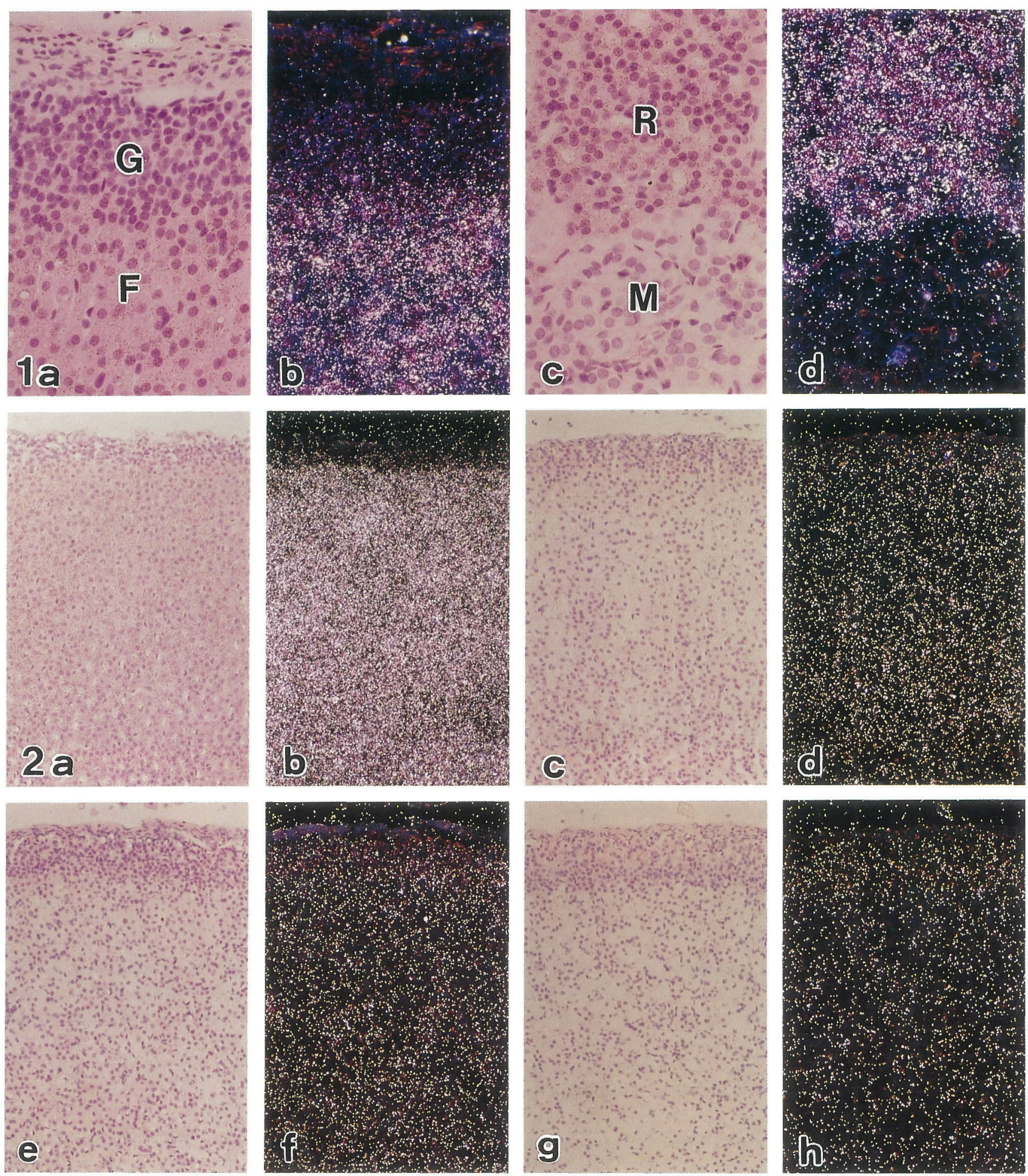

Fig. 1. Autoradiographs of a rat adrenal gland hybridized with ${ }^{35}$ S-labeled antisense Mn-SOD riboprobes. Photos were taken with a light-(a, c) and a dark-(b, d) field condenser. G: zona glomerulosa, F: zona fasciculata, R: zona reticularis, M: adrenal medulla. Expression is high in both the zona fasciculata and zona reticularis. $\times 200$.

Fig. 2. Autoradiographs of the adrenal glands of normal and hypophysectomized rats hybridized with ${ }^{35} \mathrm{~S}-\mathrm{labeled}$ antisense $\mathrm{Mn}-\mathrm{SOD}$ riboprobes. Photos were taken with a light- $(\mathbf{a}, \mathbf{c}, \mathbf{e}, \mathbf{g}, \mathbf{i})$ and a dark-( $\mathbf{b}, \mathbf{d}, \mathbf{f}, \mathbf{h}, \mathbf{j})$ field condenser under the same conditions. Expression in the normal adrenal cortex is high (a, b) while expression in the adrenal cortex 4 days (c, d), 7 days (e, f), 14 days (g, h) and 24 days $(\mathbf{i}, \mathbf{j})$ after hypophysectomy decreases gradually. M: adrenal medulla. $\times 100$. 

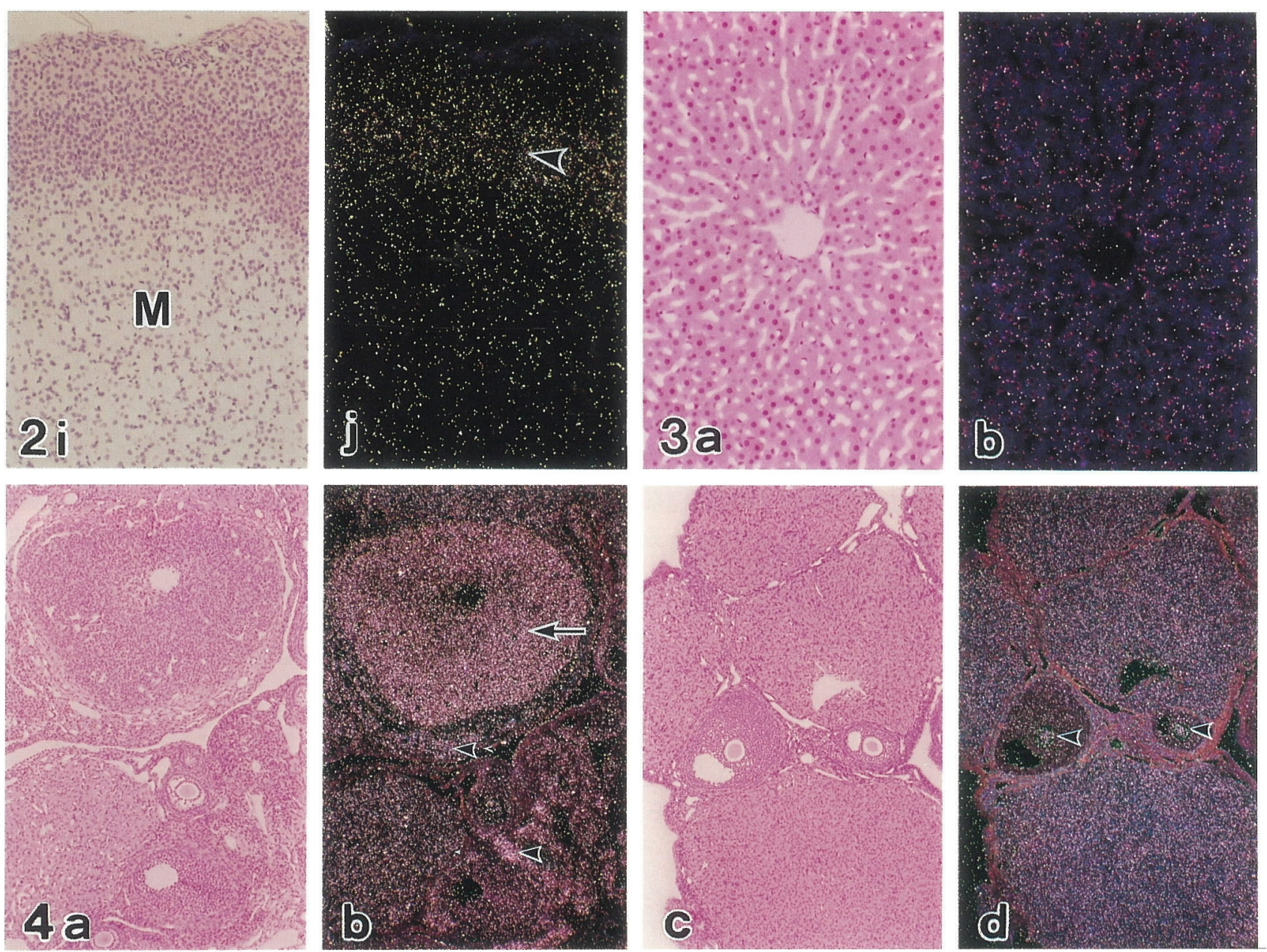

Fig. 3. Autoradiographs of normal rat hepatocytes hybridized with ${ }^{35}$ S-labeled antisense Mn-SOD riboprobes. Photos were taken with a light(a) and a dark-(b) field condenser under the same conditions as Fig. 2. The signals in the hepatocytes are lower than that in the adrenal cortex of hypophysectomized rats. $\times 100$.

Fig. 4. Autoradiographs of a rat ovary from a normal (a, b) and hypophysectomized (c, d) rat, hybridized with ${ }^{35}$ S-labeled antisense Mn-SOD riboprobes. Photos were taken with a light-(a, c) and dark-(b, d) field condenser. Expression decreases in these organs after hypophysectomy. $\times 40$.

Figs. 4 shows the ovary of a normal (Fig. 4a, b) and hypophysectomized (Fig. 4c, d) rat. Expression was highest in the epithelial (luteinizing) cells of ovulated follicles (Fig. 4b, arrow) and the stromal cells (Fig. 4b, arrowheads) of the normal ovary. After the operation, high levels of expression were only observed in the oocytes (Fig. 4d, arrowhead).

Electron microscopy of fasciculate cells was carried out with normal and hypophysectomized rats. In normal rats, mitochondria were usually round or oval in shape, and the mitochondrial cristae were usually dense and vesicular. Smooth endoplasmic reticulum was abundant around mitochondria and electron dense lipid droplets (Fig. 5a). Four days after hypophysectomy, mitochondrial cristae became scarce and tubulo-vesicular in shape (Fig. 5b). Elongated mitochondria with tubular cristae and electron-lucent lipid droplets appeared in these cells
(Fig. 5c). Fourteen days after the operation, mitochondria with scarce tubulo-vesicular cristae were still present in these cells, and these were often surrounded by smooth endoplasmic reticulum (Fig. 5d).

\section{Discussion}

This study showed that Mn-SOD mRNA was abundantly expressed in the zonae fasciculata and reticularis of the adrenal cortex of normal rats, and expression was decreased significantly by hypophysectomy. Decreased Mn-SOD expression after hypophysectomy was associated with morphological changes in the structure of mitochondrial cristae in fasciculata cells, from a vesicular shape to a tubulo-vesicular shape. Marked expression of Mn-SOD mRNA in the adrenal cortex support the hypothesis that Mn-SOD is associated with steroidogenesis, as reported 

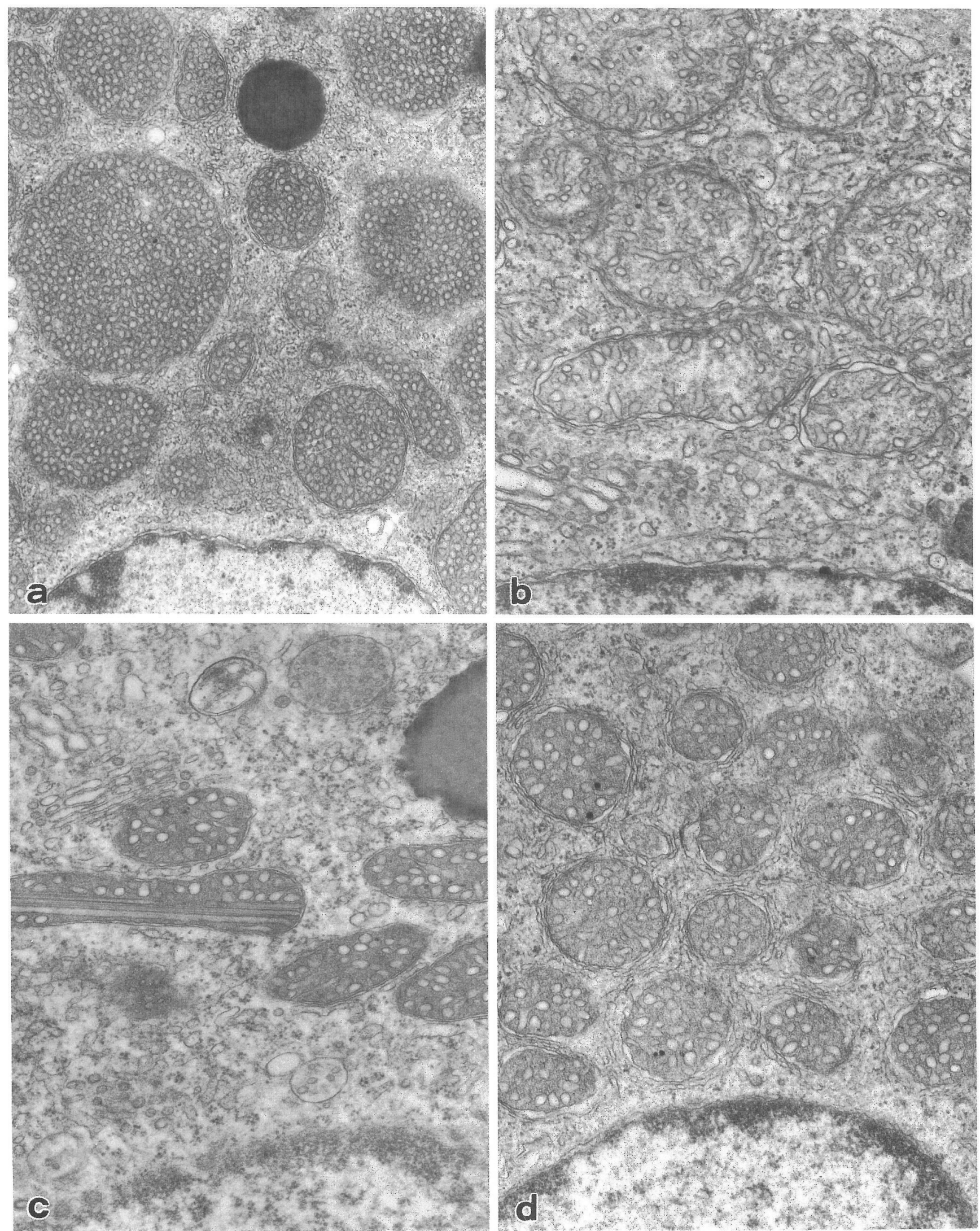

Fig. 5. Electron micrographs of fasciculate cells from a normal rat (a), and rats 4 days (b, c) and 14 days (d) after hypophysectomy. The cristae changes from vesicular to tubulo-vesicular after hypophysectomy. a $\times 21,000$, b $\times 27,000, \quad$ c $\times 26,000, d \times 26,400$. 
previously $[12,18]$. Laloraya and co-workers found an inverse correlation between the levels of superoxide radical and SOD in the ovary [10] and the uterus [11] of rats during the estrous cycle. They also observed changes in SOD activity, and the superoxide radical in luteinizing hormone (LH)-stimulated mouse Leydig cells [9]. Initially they suggested that LH-induced SOD leads to the production of hydrogen peroxide, which may play a key role in driving the peroxidase-ascorbate system responsible for the production of progesterone from pregnenolone. Previous studies in our laboratory $[12,18]$ showed that marked increases in Mn-SOD mRNA occurred first in the theca interna cells and granulosa cells of ovulated follicles, and occurred later in the corpora lutea during the ovulatory process induced by PMSG and HCG. Mn-SOD mRNA was found in cells which had begun to synthesize progesterone. Immunohistochemical studies also showed that theca interna cells were positively stained for progesterone throughout the follicular phase, while the granulosa cells in the small follicles were stained negatively at first, becoming positive during the later stages of their development. The corpora lutea was also stained positively for progesterone [8].

Hydroxysteroid dehydrogenase, which synthesizes progesterone from pregnenolone, is localized to the smooth endoplasmic reticulum (SER) membranes in cortical cells, especially the fasciculate and reticularis cells [7], while Mn-SOD is localized within the mitochondrial matrix [22] and catalyzes the dismutation of superoxide radicals to hydrogen peroxide and oxygen. The synthesis of progesterone from pregnenolone requires $\mathrm{NAD}^{+}$as a hydrogen acceptor, and hydrogen peroxide oxidizes ascorbic acid to ascorbyl radicals, which in turn oxidize NADH to $\mathrm{NAD}^{+}[20]$. Thus, the hydrogen peroxide generated by Mn-SOD in the mitochondrial matrix might pass through the mitochondrial membrane and be utilized for enzymatic reaction(s) in the smooth endoplasmic reticulum. The close association of the SER and mitochondria (Fig. 5a) supports this assumption.

Because Mn-SOD is localized specifically in the mitochondrial matrix, marked expression of its mRNA might reflect the increased generation of superoxide and hydrogen peroxide in this compartment. Sato et al. [19] reported that levels of Mn-SOD mRNA markedly increased during the ovulatory process while its enzymatic activity decreased. They suggested that the turnover of Mn-SOD (synthesis and degradation) in these cells might be accelerated significantly. An increased turnover of this enzyme may also suggest the presence of reactive oxygen species which degrade this enzyme.

It has been reported that only steroid secreting cells possess unique mitochondria, with tubular or vesicular cristae, while other cells contain mitochondria with lamellar cristae. We thought that the continued generation of reactive oxygen species may cause the formation of tubular or vesicular cristae. The high expression of MnSOD mRNA in the zona fasciculata and reticularis, and its low expression in the zona glomerulosa of the rat adrenal cortex are consistent with the morphology of their mitochondria [13, 14]. It has been reported that densely arranged vesicular cristae, representing the active state of fasciculate cells in normal rats, were transformed into a scarce tubulo-vesicular form, representing their inactive or hypo-functional state, by hypophysectomy $[1,2,5,6,13$, 14]. However, the expression of Mn-SOD mRNA in the remaining part of the cortex in hypophysectomized rats was still higher than in hepatocytes of normal rats. Thus, the formation of tubulo-vesicular cristae in fasciculata cell mitochondria might reflect the presence of reactive oxygen species rather than reflecting their inactive state. One of the reasons that expression of Mn-SOD mRNA does not disappear completely after the operation might be due to the fact that the adrenal cortex can still be stimulated directly by corticotropin releasing hormone $[1,2]$.

Our work showed marked increases in the Mn-SOD mRNA levels in cells of the adrenal fasciculata and reticularis, and suggested the possible roles of reactive oxygen species in the formation of mitochondria with tubular or vesicular cristae in steroid-secreting cells.

\section{Acknowledgments}

This work was supported by a Grant-in-Aid for Scientific Research from Ministry of Education, Science, sports and Culture, Japan. We appreciate Dr. Ye-Shin Ho (Duke University Medical Center) for the supply of EcoR I-Pst I fragments of Mn-SOD cDNA.

\section{References}

1. Bornstein, S. R., Ehrhart, M., Scherbaum, W. A. and Pfeiffer, E. F.: Adrenocortical atrophy of hypophysectomized rats can be reduced by corticotropin-releasing hormone (CRH). Cell Tissue. Res. 260; 161-166, 1990.

2. Bornstein, S. R., Ehrhart-Bornstein, M., Güse-Behling, H. and Scherbaum, W. A.: Structure and dynamics of adrenal mitochondria following stimulation with corticotropin releasing hormone. Anat. Rec. 234; 255-262, 1992.

3. Cox, K. H., DeLeon, D. V., Angerer, L. M. and Angerer, R. C.: Detection of mRNA in sea urchin embryos by in situ hybridization using asymmetric RNA probes. Dev. Biol. 101; 485-502, 1984.

4. Dobashi, K., Asayama, K., Kato, K., Kobayashi, M. and Kawaoi, A.: Immunohistochemical localization of copper-zinc and manganese superoxide dismutase in rat tissues. Acta Histochem. Cytochem. 22; 351-365, 1989.

5. Fujita, H.: On the fine strucute of alteration of the adrenal cortex in hypophysectomized rats. Z. Zellforsch. 125; 480-496, 1972.

6. Idelman, S.: Ultrastructure of the mammalian adrenal cortex. Int. Rev. Cytol. 27; 181-281, 1970.

7. Ishimura, K., Yoshinaga-Hirabayashi, T., Fujita, H., IshiiOhba, H., Inano, H. and Tamaoki, B.: Light and electron microscopic immunocytochemistry on the localization of $3 \beta$ hydroxyeteroid dehydrogenase/isomerase in the bovine adrenal cortical cells. Histochemistry 89; 35-39, 1988.

8. Kobayashi, M., Nakano, R. and Ooshima, A.: Immunohistochemical localization of pituitary gonadotrophins and 
gonadal steroids confirms the 'two-cell, two-gonadotrophin' hypothesis of steroidogenesis in the human ovary. J. Endocrinol. 126; 483-488, 1990.

9. Kumar, G. P., Seerwani, N., Laloraya, M., Nivsarkar, M., Verma, S. and Singh, A.: Superoxide dismutase as a regulatory switch in mammalian testicular steroidogenesis. Biochem. Biophys. Res. Commun. 173; 302-308, 1990.

10. Laloraya, M., Kumar, G. P. and Laloraya, M. M.: Changes in the levels of superoxide anion radical and superoxide dismutase during the estrous cycle of Rattus norvegicus and induction of superoxide dismutase in rat ovary by lutropin. Biochem. Biophys. Res. Commun. 157; 146-153, 1988.

11. Laloraya, M., Kumar, G. P. and Laloraya, M. M.: Changes in the superoxide radical and superoxide dismutase levels in the uterus of Rattus norvegicus during the estrous cycle and a possible role for superoxide radical in uterine oedema and cell proliferation at proestrus. Biochem. Cell Biol. 69; 313-316, 1991.

12. Nomura, T., Sasaki, J., Mori, H., Sato, E. F., Watanabe, S., Kanda, S., Matsuura, J., Watanabe, H. and Inoue, M.: Expression of manganese superoxide dismutase mRNA in reproductive organs during the ovulatory process and the estrous cycle of the rat. Histochem. Cell Biol. in press.

13. Nussdorfer, G. G.: Cytophysiology of the adrenal zona glomerulosa. Int. Rev. Cytol. 64; 307-368, 1980.

14. Nussdorfer, G. G., Mazzocchi, G. and Meneghelli, V.: Cytophysiology of the adrenal zona fasciculata. Int. Rev. Cytol. 55; 291-365, 1978.

15. Pardue, M. L.: In situ hybridization. In "Nucleic Acid Hybridization: A Practical Approach”, ed. by B. D. Hames and
S. J. Higgins, IRL Press Ltd., Oxford and Washington D.C., 1985, pp. 179-202.

16. Sasaki, J., Nomura, T., Watanabe, S., Kanda, S., Sato, E. F., Takehara, Y. and Fujii, Y.: In situ hybridization at light and electron microscopic levels. J. Clin. Electron Microscopy 25; 338-339, 1992.

17. Sasaki, J., Watanabe, S., Nomura, T., Kanda, S., Yamaai, T., Koyama, E., Noji, S. and Taniguchi, S.: Synthesis of actin in the nonciliated bronchiolar epithelial (Clara) cells of perinatal rats demonstrated by electron microscopy and in situ hybridization. Acta Histochem. Cytochem. 23; 453-465, 1990.

18. Sasaki, J., Sato, E. F., Nomura, T., Mori, H., Watanabe, S., Kanda, S., Watanabe, H., Utsumi, K. and Inoue, M.: Detection of manganese superoxide dismutase mRNA in the theca interna cells of rat ovary during the ovulatory process by in situ hybridization. Histochemistry 102; 173-176, 1994.

19. Sato, E. F., Kobuchi, H., Edashige, K., Takahashi, M., Yoshioka, T., Utsumi, K. and Inoue, M.: Dynamic aspects of ovarian superoxide dismutase isozymes during the ovulatory process in the rat. FEBS Lett. 303; 121-125, 1992.

20. Shiotani, M., Noda, Y., Narimoto, K., Imai, K., Mori, T., Fijimoto, K. and Ogawa, K.: Immunohistochemical localization of superoxide dismutase in the human ovary. Human Reproduct. 6; 1349-1353, 1991.

21. Sies, H.: Oxidative Stress. Academic Press, London, 1985.

22. Slot, J. W., Geuze, H. J., Freeman, B. A. and Crapo, J. D.: Intracellular localization of the copper-zinc and manganese superoxide dismutases in rat liver parenchymal cells. Lab. Invest. 55; 363-371, 1986. 